\title{
Assessment of quality of life among patients attending HIV clinics in Ilorin metropolis
}

\author{
Ahmed A. ${ }^{1}$, Uthman M.M.B. ${ }^{2}$, *Osinubi M.O. ${ }^{1}$, Bolarinwa A.O. ${ }^{2}$, Musa O.I. ${ }^{2}$, \\ Aderibigbe A.A. ${ }^{2}$
}

\begin{abstract}
Objectives: The Sub-Saharan Africa (SSA), is being hit hard by the epidemic of Acquired Immunodeficiency Syndrome (AIDS) and carries the globe's heaviest burden of HIV/AIDS. HIV/AIDS has been transformed into a chronic condition, albeit one with no cure, making it important to assess determinants of quality of life (QoL) and, if required, improve the QoL of People Living with HIV (PLHIV). The study assessed the determinants of quality of life of patients attending HIV clinics in Ilorin metropolis.
\end{abstract}

Methods: The study was a descriptive cross sectional study. A sample size of 384 HIV positive patients who were systematically recruited at the 5 public service delivery sites in Ilorin. Data was analyzed using SPSS software version 20.0. Level of significance was pre-determined at $p$-value $<0.05$ at a confidence level of $95 \%$.

Results: Majority 213 (55.5\%) of the respondents had good QoL, while 171 (44.5\%) had low QoL with overall Mean score of $68 \pm 14$. This study showed that being employed, high income, and low cost of care were associated with good health related (HRQoL). Regression analysis revealed that age $>30 \mathrm{yrs}$ (odds $=$ 1.5), longer duration on Highly Active Anti-retroviral Therapy (HAART) $>3$ yrs (Odds $=1.5)$, CD4 count $>500 \mathrm{cells} / \mathrm{mm}^{3}($ Odds $=1.2)$, high monthly income $($ Odds $=1.6)$ and low cost of care (Odds $\left.=1.27\right)$ were found to determine good QoL.

Conclusion: Government should therefore expand access to HIV care by considering more Primary Health Care facilities as Anti-Retroviral Therapy (ART) treatment centers.

Key words: Quality of life, Human Immunodeficiency Virus, Patients, Anti-Retroviral Therapy

\author{
*Correspondence author \\ Dr Osinubi M.O., \\ http://orcid.org/0000-0001-6534-0135 \\ E-mail:omobolayusf@yahoo.com \\ ${ }^{1}$ Department of Community Medicine and Primary Care, Federal Medical Centre, Abeokuta \\ ${ }^{2}$ Department of Epidemiology and Community Health, University of Ilorin
}

Research Journal of Health Sciences subscribed to terms and conditions of Open Access publication. Articles are distributed under the terms of Creative Commons Licence (CC BY-NC-ND 4.0). (http://creativecommons.org/licences/by-nc-nd/4.0)

http://dx.doi.org/10.4314/rejhs.v6i4.9 


\title{
Évaluation de la qualité de vie des patients fréquentant des centres de traitement du VIH dans la métropole d'Ilorin
}

\author{
Ahmed A. ${ }^{1}$, Uthman M.M.B. ${ }^{2}$, Osinubi M.O. ${ }^{1}$, Bolarinwa A.O. ${ }^{2}$, Musa O.I. ${ }^{2}$, \\ Aderibigbe A.A. ${ }^{2}$
}

\begin{abstract}
Resume
Objectifs: L'Afrique subsaharienne (ASS) est durement touchée par l'épidémie de syndrome d'immunodéficience acquise (SIDA) et porte le fardeau le plus lourd du VIH / SIDA au monde. Le VIH / sida est devenu une maladie chronique, même si elle n'est pas guérie, ce qui rend importante l'évaluation des déterminants de la qualité de la vie et, si nécessaire, l'amélioration de la qualité de vie des personnes vivant avec le VIH (PVVIH). L'étude a évalué les déterminants de la qualité de vie des patients fréquentant des centres de traitement du VIH dans la métropole d'Ilorin.
\end{abstract}

Méthodes: L'étude était une étude descriptive transversale. Un échantillon de 384 patients séropositifs qui ont été systématiquement recrutés dans les 5 sites de prestation de services publics à Ilorin. Les données ont été analysées à l'aide du logiciel SPSS version 20.0. Le niveau de signification a été prédéterminé à une valeur $\mathrm{p}<0,05$ avec un niveau de confiance de $95 \%$.

Résultats: La majorité des répondants (55,5\%) avaient une bonne qualité de vie, tandis que 171 (44,5\%) avaient une faible qualité de vie avec un score moyen global de $68 \pm 14$. Cette étude a montré que le fait d'avoir un emploi, un revenu élevé et un coût de soins peu élevé était associé à une bonne santé (HRQoL). L'analyse de régression a révélé que l'âge $>30$ ans (probabilité $=1,5$ ), une durée plus longue du traitement antirétroviral hautement actif (HAART) $>3$ ans (probabilité $=1,5)$, un nombre de CD4>500 cellules / mm3 (probabilité $=1,2$ ), un revenu mensuel élevé $=1,6$ ) et le faible coût des soins (probabilité $=1,27$ ) ont été jugés déterminants pour la qualité de vie.

Conclusion: le gouvernement devrait donc élargir l'accès aux soins du VIH en considérant davantage d'établissements de soins de santé primaires comme centres de traitement antirétroviraux.

Mots-clés: qualité de vie, virus de l'immunodéficience humaine, patients, traitement antirétroviral

\author{
* Auteur de la correspondance \\ Dr Osinubi M.O., \\ http://orcid.org/0000-0001-6534-0135 \\ E-mail: omobolayusf@yahoo.com \\ ${ }^{1}$ Department of Community Medicine and Primary Care, Federal Medical Centre, Abeokuta \\ ${ }^{2}$ Department of Epidemiology and Community Health, University of Ilorin
}




\section{INTRODUCTION}

The Sub-Saharan Africa (SSA), is being hit hard by the epidemic of Acquired Immunodeficiency Syndrome (AIDS) and carries the globe's heaviest burden of HIV/AIDS (1). A recent Human Immunodeficiency Virus (HIV) sero-prevalence figure of $3.4 \%$ represents about 3.5 million people infected with HIV, ranking Nigeria third among the countries with the highest HIV/AIDS burden in the world, next only to India and South Africa. The NorthCentral zone which Kwara State belongs to has highest concentration of HIV prevalence rate of $7.5 \%$, while the North-Western zone recorded the lowest prevalence of $2.1 \%$; Kwara state has a prevalence rate of $2.2 \%(1)$.

Economic evaluations of HIV/AIDS interventions can largely be divided into two groups; studies that ignore improvement in health related quality of life and those that seek to capture such improvements. While the former group of studies focus on simple clinical outcomes such as mortality or averted cases of HIV, the latter attempt to capture effect changes both in terms of life expectancy and improvements in health states. This is typically being done either by estimating quality adjusted life year (QALY) or disability adjusted life year (DALY). A basic premise for QALY analyses is that they depend on HRQoL weights that should reflect people's preferences (2). Cost per DALY analyses depend on disability weights, that in country specific applications also are meant to be adapted to local circumstances (3).

Allocation of more resources on treatment programmes for people living with HIV/AIDS has received high international pressure, which is important given the magnitude of the epidemic. However, the comparison of health outcomes (such as improved quality of life) with cost is a crucial issue in the evaluation of alternative programmes across different disease group. HIV/AIDS has been transformed into a chronic condition, albeit one with no cure, making it important to assess determinants of quality of life $(\mathrm{QoL})$ and, if required, improve the QoL of PLWHIV (4).

Assessment of determinants of QoL is vital to understanding the impact of both HIV and ART on people's lives (5). Progress has been made in assessing QoL among People Living with HIV (PLWHIV) in developed countries and QoL outcomes have been used in decision making about ARV regimens (6-10). Decreased quality of life among other morbid conditions is associated with chronic HIV infection (11). It has been reported in various studies that presence of HIV as well as its symptoms and complications have a negative effect on the quality of life of people living with HIV/AIDS (11-13). Annual number of new infection in Nigeria remains high $(310,620)$ despite the reported $8.8 \%$ decrease from 2008 estimates of 340,015. Annual mortality resulting from AIDS increased from 192000 in 2008 to 217,148 in 2012 (14).

Many studies have focused on health outcomes in terms of increased longevity from HIV/AIDS treatments (15-18), but there appears to be limited research measuring outcomes in terms of improved health related quality of life (HRQoL) (19). The study assessed the quality of life of patients attending HIV clinics in Ilorin metropolis and also identified some determinants of health-related quality of life among these patients.

What is already known about the study?

It has been shown that early initiation of treatment is cost-effective in the long run (10)

- It has been observed from previous studies that there is increased longevity from HIV treatment (19)

What this study adds

The study demonstrated that there is improved quality of life among patients on Anti-retroviral therapy

This study showed that being employed, high income, and low cost of care were associated with good health related quality of life

\section{METHODS \\ Description of the Study Area}

The study was conducted in Ilorin the capital city of Kwara State, Nigeria. It is located at the geographical and cultural confluence of the North and South of Nigeria (in the North Central geopolitical zone) with a landmass of $32,500 \mathrm{~km} 2$. It lies between longitude $80 \mathrm{~N}$ and latitude 40S. In distance, Ilorin is about 302 kilometers North of Lagos, 602 kilometers South of Kaduna and about 475 kilometers South of Abuja, the Federal capital of Nigeria. It hosts a projected population of 854,737 based on the 2006 National Census and annual growth rate of $3.2 \%(1)$.

Ilorin is made up of three Local Government Areas (LGAs), namely: Ilorin East LGA, Ilorin West LGA and Ilorin South LGA; with their headquarters at Oke-Oyi, Wara and Fufu respectively. Ilorin East and South LGAs have 11 Wards each, while Ilorin West LGA has 
12 Wards; all totalling 34 Wards in Ilorin metropolis. The indigenous people are mainly Yoruba and Hausa-Fulani. Other tribes include Hausa, Igbo, Nupe, Baruba and other ethnic groups of Nigeria. The major religions are Islam and Christianity. The occupations of the residents in Ilorin include civil service, commercial driving, trading, farming, artisans, organized private sector and weaving of traditional attires.

There are five (5) Public HIV treatment centres in Ilorin metropolis, one tertiary health centre; University of Ilorin Teaching Hospital (U.I.T.H). Other HIV treatment centres are Sobi Specialist Hospital, Kwara State Civil Service Clinic and Children Specialist Hospital, Centre Igboro, Ilorin which are secondary health facilities and Cottage Hospital, Adewole - a primary health centre. These facilities are focused and accredited centres for the treatment of HIV positive patients in a clinical setting not just providing HCT and PMTCT of HIV. University of Ilorin Teaching Hospital has a designated outpatient ART clinic building for care of patients and runs daily clinic. It also serves as referral centre to other communities outside Kwara and has the highest number of patients' turnout. Other treatment centres run ART clinic from Monday to Friday as well concurrently with the general clinic. ARV services in Kwara state is currently being supported by two NonGovernmental Organizations; Management Science for Health (MSH) which caters for the Public Health facilities and Hygiea which supports private health facilities in the State. Apart from the above mentioned accredited ART centres, there are 32 HIV Counselling and Testing (HCT) sites distributed across various Primary health facilities in Ilorin metropolis (20).

Study Design: This was a descriptive cross sectional study of respondents examining the HRQoL and its determinants in a sample of 384 HIV Patients receiving care at the 5 public service delivery sites.

Study Population: This covered adults HIV Patients aged 18 years and above receiving ART services at the various health facilities in the study area.

Sample Size Determination: The minimum sample size was determined using the Fischer's formula for obtaining sample size when the population is less than 10,000 for descriptive studies.

$$
\mathrm{N}_{\mathrm{f}}=\mathrm{n} / 1+(\mathrm{n} / \mathrm{N})[]
$$

Value of $\mathrm{n}$ was calculated using the formular

Where:

$$
\mathrm{n}=\mathrm{Z}^{2} \mathrm{pqd}^{2}
$$

$\mathrm{n}=$ the desired sample size (when population is greater than 10,000 )

$\mathrm{z}=$ the standard normal deviate, usually set at 1.96 , which corresponds to the $95 \%$ confidence level.

$\mathrm{P}=$ HRQOL score among HIV patients in a subSaharan African country (Uganda) was 55 (0.55) (22)

$$
\begin{aligned}
& \mathrm{q}=1.0-\mathrm{p} \\
& \mathrm{d}=\text { degree of accuracy, set at } 0.05 \text { for this } \\
& \text { study }
\end{aligned}
$$

Therefore:

$$
\begin{aligned}
& \quad \mathrm{n}=\frac{(1.96)^{2}}{(0.55)(0.45)} \\
& \quad=380 \\
& \mathrm{n}_{\mathrm{f}}=\mathrm{n} / 1+(\mathrm{n} / \mathrm{N}) \\
& \mathrm{n}_{\mathrm{f}}=\text { minimum sample size when target population } \\
& \text { is less than } 10,000 \\
& \mathrm{~N}=\text { the estimate of HIV patients on ART in Ilorin } \\
& \text { which is } 3,908 \\
& \mathrm{n}_{\mathrm{f}}=380 / 1+(380 / 3908) \\
& \mathrm{n}_{\mathrm{f}}=346 \\
& \text { Adjustment for Non-Response } \\
& \text { The minimum sample size; } \mathrm{N}=\mathrm{n} /(100-\mathrm{r} \%) \\
& \text { Where } \mathrm{r} \% \text { was the anticipated non response rate, } \\
& \text { which is } 10 \% \quad \mathrm{O} \% \\
& \text { Substituting; } \mathrm{N}=346 /(100 \%-10 \%) \\
& =346 /(0.9) \\
& =384
\end{aligned}
$$

The sample size required for this study was 384 .

Sampling Technique: A systematic sampling technique was used for the selection of 384 respondents.

Data Collection Methods: Data were collected directly from each site as well as from a sample of adult patients presenting at HIV clinics, this was by interviewer-administered questionnaires. Six research assistants (sourced among resident Doctors and volunteer workers working in HAART clinic) were recruited and trained for two days to assist in data collection. The quality of life (QOL) instruments used for this study were multidimensional Measure of Internalized HIV Stigma Scale, Brief COPE Scale and The WHO QOL-HIV bref which is an abbreviated version of WHO QOL-HIV. The WHOQOL-HIV-bref is based on WHOQOL-bref, it evaluates the quality of life from six domains (Physical, Psychological, Level of Independence, Social Relations, Environment and Spiritual / Religion / 
Personal Beliefs) and 29 facets. Data was collected on every working day (Mondays to Fridays) for four weeks.

Pre-Testing of research Instruments: The instrument was pretested in about $10 \%$ of the required sample size among HIV patients attending ARV clinic at Omu-Aran, Irepodun Local Government Area, Kwara State having similar characteristics with the study area. The pre-tested instruments were analysed to detect possible problems in the validity of the research tools. The problems identified were corrected in subsequent questionnaire design for the proper research.

Statistical Analyses: Data collected presented in prose and frequency tables. Frequency distribution and other relevant summary statistics generated. Appropriate tests of significance (chisquare test and Regression analysis) used to test statistic. Statistical significance was set at pvalue $<0.05$. For each domain lower scores indicated poor self perceived quality of life for that health measure. The sub-scales of the instrument were scored as summated rating scales on a $0-100$ scale. The reference point was the Mean score \pm two Standard Deviations (SD). Respondents who scored $<$ 2SD were classified as those with poor QoL while those $\geq 2$ SD were classified as those with good QoL. The construct validity of the instrument was analysed using a correlation matrix. Multiple logistic regression was performed to analyse the relationship between the dependent variable (QoL) and the independent variables such as sociodemography, income, employment, clinical status e.t.c.

Ethical Considerations: Ethical clearance to conduct the study was obtained from the ethical review committee of University of Ilorin Teaching Hospital before the commencement of the study. Patient interviews were conducted in privacy and anonymously. Respondents were informed about the objectives of the study and that the data collected will be treated with confidentiality. Written informed consent was obtained from all respondents signed or thumb print before the start of the interview, with interviews lasted for approximately 30-45 minutes.

Limitation: Because there is no criterion or "gold standard" for HRQL, it was a challenge to determine whether any HRQL measure is tapping into the intended aspect of peoples' experience. This study therefore tried to reduce this limitation by using validated instruments (WHOQOL-HIV Bref, Brief Cope and HIV Stigma scale).

\section{RESULTS}

A total of 384 patients attending HIV clinics in Ilorin were recruited from five public health facilities and completed the questionnaires used for analysis.

Patients' ages ranged from 19 to 72 years with mean age $42.68 \pm 10.76$. The monthly income of respondents ranges from as low as N2, 000 to N150, 000 with the average monthly income of N24, 900. Patients travel to the facilities from as close as $3 \mathrm{KM}$ to as far as $400 \mathrm{KM}$ with average distance of $42.87 \mathrm{KM}$. The number of dependents ranged from none to as high as twelve.

Table 1 shows that the modal age group was $41-50 y r s(34.9 \%)$. Majority of the patients were females constituting 58\%, 77.6\% were married while $11.5 \%$ were widowed and over one-fifth 89 (21.9\%) were unemployed. Majority $287(74.7 \%)$ of the respondents earned less than $\mathrm{N} 20,000$ in a month while Islam is the major religion practiced by respondents $54.7 \%$.

Table 2 assessed the level of stigma experienced by the respondents. As many as over two-thirds $258(67.2 \%)$ of the respondents expressed strong concern regarding disclosure, three-quarters $298(77.6 \%)$ of them reported poor weak relationship compared to $86(22.4 \%)$ that reported strong social relationship, while up to $155(40.4 \%)$ reported weak self acceptance of their health condition.

Participants' quality of life was good in all the domains except spiritual/religion/belief domain where only $39.6 \%$ of the respondents had good Qol. $171(44.5 \%)$ of the respondents had low QoL while 213 (55.5\%) had good QoL, see table 3 .

Table 4 revealed identified determinants of QoL in this study. Respondents whose ages were more than 30yrs had a higher odd of good QoL $(\approx 1.5)$ than those whose age was below $30 y$ rs. Likewise, income status revealed that respondents earning $>$ N 20, 000 recorded higher odd of better QoL $(\approx 1.6)$ compared to 1.2 of those earning less. Other factors that predicted better QoL are longer duration on HAART, higher CD4 count and less spending on care. Those who have been on HAART for up to $3 y$ rs and beyond were about 1.5 times better than respondents who were less than 3 yrs on HAART. Similarly, higher CD4 count of $>500$ cells 
predicted better QoL with odds of $\approx 1.2$ while those with $<500$ cells did not predict. Respondents who spent less than N1, 000 in accessing care had higher odds of better QoL (1.27) than those who spent more than N1, 000 with odds of 1.24. Factors such as gender, employment status, tertiary level of education, marital status did not predict good QoL in this survey.

\section{DISCUSSION}

The aim of this study is to assess and identify the determinants of quality of life among Patients attending HIV clinics in Ilorin. The age distribution of respondents ranged from 19 to 72 years. Those aged between 30 and 50 years constituted the majority of the patients, with mean age of $42.68 \pm 10.76$ years. This is found to be higher than the age distribution observed in a similar study among HIV patients in Uganda where largest proportion of patients age ranged from 25-35 years (23).

Majority of the patients were females constituting 58\%, 74.2\% were married while $11.5 \%$ were widowed and over one-fifth $(21.9 \%)$ were unemployed. This finding is similar to a Ugandan study where study population had more women (71\%) than men (4). This is consistent with the clinic population from where participants were drawn, with approximately $70 \%$ of the PLHIV being women (24). Other studies in Uganda and South Africa reported a range of $60-75 \%$ to be female $(25,26)$. The probable reasons for females being majority are likely due to early diagnosis of HIV during Ante natal screening and unwillingness of men to come for screening.

Only about $16.3 \%$ of the respondents travelled for less than 30 minutes to access care, while $23.7 \%$, travelled for up to 2 hours and $10.7 \%$ travelled for more than 3 hours in accessing care. About half (49.2\%) travelled for up to an hour. Clinic waiting time was as long as 2 to 3 hours by more than a quarter $(28.6 \%)$ of the respondents to access care, while only $21.9 \%$ wait for less than an hour. The implication of these findings is that there is a relative gap in accessing HIV care. This is in support of WHO's report on "Towards Universal Access" which affirmed that only $31 \%$ of people who needed treatment for HIV infection received it (27).

Two hundred and thirteen (55.5\%) of the respondents had good QoL, while 171 (44.5\%) had low QoL. The Mean reference point for the overall quality of life among patients attending HIV clinics in Ilorin is $68 \pm 2 \mathrm{SD}$ for which QoL was classified as good or poor. This is found to be higher than the reported score of 55 in a study of Utility assessment of HIV/AIDS-related health states in HIV-infected Ugandans (22), however, this is lower than the reported 78 in an Italian study which analyzed the QoL among HIV patients on HARRT (28). The difference could be due to higher socio-economic status of Italy in relation to the sun-Saharan African countries such as Uganda and Nigeria.

As many as over two-thirds (67.25\%) of the respondents expressed strong concern regarding disclosure of their status. Over threequarters $(77.6 \%)$ of them reported weak social relationship compared to $22.4 \%$ that reported strong social relationship, while $40.4 \%$ reported weak self acceptance of their health condition. The implication of this concern could probably be due to the fear of stigma that might be experienced following disclosure. An Australian study revealed that experiencing stigma negatively influenced HRQoL (29) and similar study in France reported that stigma and disclosing sero-positive status have negative effects on both physical and mental health (30). The latter relationship, however, remained unclear, because disclosure could also be beneficial for the patient's mental and physical health (mainly through social support) (31). However, it could potentially be related to the fact that people with worse HRQoL have to disclose their seropositive status because of the symptoms, and may feel forced to do so instead of voluntarily doing so. Multiple regression analysis of variables that were considered as predictors of good QoL in this study showed that Respondents whose ages were more than 30yrs had a higher odds of good QoL $\approx 1.5$ (95\%C.I $=$ $0.5-3.9)$ than those below 30yrs.

Longer duration on HAART appeared to predict better QoL as those who have been on HAART for up to $3 y r s$ and beyond were about 1.5 (95\% CI 0.85 to 2.99 ) times better than respondents who were less than 3yrs on HAART who had odds of 0.7 . This finding is in keep with a review of studies which showed relationship between longer duration on ART and HRQoL (32). More adherent PLWHIV probably had better virological and immunological outcomes and could therefore have a better HRQoL.(32). Recent studies in the United States on simplification strategy that improves adherence and quality of life of HIV infected Subjects showed a positive effect of ART use on HRQoL $(33,34)$. Meanwhile, two different studies revealed opposing findings as regards duration 
on ART; A longer time since diagnosis was associated with both lower (35) and higher mental health (36). Similarly, higher CD4 count of $>500$ cells predicted better QoL as the odds of Respondents with $>500$ cells was $\approx 1.2(95 \% \mathrm{CI}=$ 0.65 to 2.10 ) times better than 0.60 of those with $<500$ cells. Studies all over the world established that a higher CD4-cell count was associated with a better HRQoL (18) and also a predictor of good QOL $(30,35,37)$. Respondents who spent less than N1, 000 in accessing care had higher odds of better QoL (1.27) than those who spent more than N1, 000 with odds of 1.24 Income status revealed that Respondents earning $>$ N 20, 000 recorded higher odds of better QoL (odds $\approx 1.6(95 \% \mathrm{CI}=$ $0.6-2.1)$ compared to 1.2 of those earning less. These findings were closely related to a cohort study assessing factors of QoL among HIV Patients in urban Uganda which estimated that HIV Patients earning more than $\$ 60$ had the odds of $1.42(95 \%$ CI 0.96 to 2.10$)$ relative to a person in the category earning less than $\$ 20$ per month (4). Similar significant regression analysis demonstrating association between income and being employed was reported in Italy (28). Factors such as gender, employment status, tertiary level of education, marital status did not predict good QoL in this study.

\section{CONCLUSION}

HIV is a chronic disease with heavy burden on both patients and health facility rendering services for the care of these patients. It also poses a serious economic and financial burden on both patients and the country at large. Productive adults largely 30 years and above and females constituted the majority of the respondents attending HIV clinics in the study areas. Though, about three-quarters $(74.7 \%)$ of the respondents were employed, same proportion earned less than N20, 000 a month.

Two hundred and thirteen $(55.5 \%)$ of respondents had good QoL, while 171 (44.5\%) had low QoL with overall Mean score of $68 \pm 14$. This study showed that being employed, high income, and low cost of care were associated with good HRQoL (in all the domains except Spiritual where low cost of care did not imply good QoL). Furthermore, regression analysis revealed that age $>30 y$ rs, longer duration on HAART $(>3 y r s$, CD4 count $>500$ cells $/ \mathrm{mm}^{3}$, high monthly income and low cost of care were determinants of good QoL.

This study therefore recommends that; HIV awareness and prevention campaign targeted at the productive adults and females (by all stakeholders) should be sustained as they constituted the major population affected as revealed in this study.

Since being employed, high income and low cost of care were found to determine good QoL and majority of the population being affected are within the productive age group, efforts by government, corporate bodies, well meaning individuals and families should be geared towards creating enabling environment for the empowerment of those affected with HIV

Conflict of Interest: None to declare

\section{REFERENCES}

1. National Population Commission - NPC/Nigeria, ICF international. Nigeria Dempgraphic and Health Survey 2013, Abuja, NPC/Nigeria and ICF international 2014.

2. Drummond M.F, Schulper M.J, Torrance G.W, O'Brien B.J, (2005) SGL. Methods for the Economic Evaluation of Health Care Programmes. 3rd ed ed. Oxford, UK:: Oxford University Press.; 2005.

3. Murray C.J.L AAK. Understanding DALYs. Journal of Health Economics. 1997;16(6):703-30.

4. Doris M.M AK, Faith M, Janet S, Albert W.W, . Factors That Affect Quality of Life among People Living with HIV Attending an Urban Clinic in Uganda: A Cohort Study. PLOS ONE. 2015.

5. Mills E.J BC, Birungi J, Chan K, Ford N, Cooper C.L, et al. Life Expectancy of Persons Receiving Combination Antiretroviral Therapy in LowIncome Countries: A Cohort Analysis From Uganda. Annals of Internal Medicine. 2011;155(4):209-16.

6. Wu A.W. Quality of life assessment comes of age in the era of highly active antiretroviral therapy. AIDS. 2000;14:1449-51.

7. Murri R FM, Del B.C, Visona R, Barracco A, Zambelli A, et al. Determinants of health-related quality of life in HIV-infected patients. AIDS Care. 2003;15(4):581-90.

8. De Castro N, Braun J, Charreau I, Pialoux G, Cotte L, Katlama C. Switch from Enfuvirtide to Raltegravir in Virologically Suppressed Multidrug-Resistant HIV-1-Infected Patients: A Randomized Open-Label Trial. Clinical Infectious Diseases. 2009;49:1259-67.

9. Briongos F.L.S BLP, Palacios M.T, González S.M, Eiros B.J.M Assessment of factors influencing health-related quality of life in HIVinfected patients. HIV Medicine. 2011;12:22-30.

10. Jelsma J ME, Hughes J, Tinise X, Darder M. An investigation into the health-related quality of life of individuals living with HIV who are receiving HAART. AIDS Care. 2005; 17:579-88.

11. Bopp C.M, Phillips K.D, Fulk L.J, Hand G.A. Clinical implications of therapeutic exercise in HIV/AIDS. J Assoc Nurses AIDS Care. 
2003;14(1):73-8.

12. UNGASS, country, progress, report. Nigeria; 2010.

13. Dropulic B, Humeau L, Binder G.K, Lu X, Slepushkin V, Merling R, et al. HIV-1-derived lentivirus vector-based antisense gene therapy:towards an alternative treatment for HIV/AIDS. Mol Ther. 2004;9(1003):384.

14. Federal Republic of Nigeria. Global AIDS Response Country Progress Report. Nigeria2012.

15. Braitstein P. Mortality of HIV-1-infected patients in the first year of antiretroviral therapy: comparison between low-income and highincome countries. Lancet. 2006;367(9513):817-24.

16. Badri M, Lawn S.D, Wood R. Short-term risk of AIDS or death in people infected with HIV-1 before antiretroviral therapy in South Africa: a 1 o n g i t u d i n a 1 s t u d y. L a n c e t. 2006;368(9543):1254-9.

17. Jerene D, et, al. Predictors of early death in a cohort of Ethiopian patients treated with HAART. BMC Infect Dis. 2006;6(136).

18. Etard JF, et, al. Mortality and causes of death in adults receiving highly active antiretroviral therapy in Senegal: a 7-year cohort study. Aids. 2006;20(8):11181-9.

19. Bjarne R, Jan A O. The health related quality of life of people living with HIV/AIDS in subSaharan Africa - a literature review and focus group study. Cost Effectiveness and Resource Allocation 2010;8(5).

20. Healtlh KSMo. HIV M\& E. In: HIV Unit E, editor. 2015.

21. MO A. Sample size determination. Research Methodology with statistics for health and social sciences. Ilorin: mathadex; 2003. p. 118-20.

22. Lara AM. Utility assessment of HIV/AIDSrelated health states in HIV-infected Ugandans. AIDS. 2008;22(1):123-30.

23. Moreland S, Namisango E, Paxton A, Powell RA. The costs of HIV treatment, care and support services in Uganda. Measure Evaluation, February, 2013.

24. WHO, UNAIDS, UNICEF. 'Towards universal access: scaling up priority HIV/AIDS interventions in the health sector'. 2008

25. Sekabira R N-MJ, Makumbi F, Kiwanuka N, Kiweewa F, Wambwire Mangen F Determinants of Health-Related Quality of Life among Adults in Routine HIV Care,2012; 1:515 2012515 Contract No.: 515 .

26. Stangl A.L WN, Mermin J, Awor A.C, Bunnell R.E. Trends and predictors of quality of life among HIV-infected adults taking highly active antiretroviral therapy in rural Uganda. AIDS Care. AIDS Care. 2007;19:626-36.

27. WHO/UNAIDS/UNICEF. 'Towards Universal Access: Scaling up priority HIV/AIDS interventions in the health sector'. 2010.

28. Hubben G.A.A, Bishai D, Pechlivanoglou P, Cattelan A.M, Grisetti R, Facchin C, et al. The societal burden of HIV/AIDS in Northern Italy: An analysis of costs and quality of life, . AIDS Care: Psychological and Socio-medical Aspects ofAIDS/HIV,. 2008;20(4):449-55.

29. Herrmann S ME, Hyland N.B, Lalanne C, Mallal S, Nolan D, Chassany O, Duracinsky M,. HIVrelated stigma and physical symptoms have a persistent influence on health-related quality of life in Australians with HIV infection. Health Qual Life Out 2013;11.

30. Preau M MF, Carrieri M.P, Lert F, Obadia Y, Spire B. Health-related quality of life in French people living with HIV in 2003: results from the national ANRS-EN12-VESPA Study. AIDS. 2007;21:1927.

31. Serovich JM. A test of two HIV disclosure theories. Aids Educ Prev 2001;13:355-64.

32. Geocze L MS, De Marco MA, Nogueira-Martins LA, Citero VD. Quality of life and adherence to HAART in HIV-infected patients. Rev Saude Publ. 2010;44(7):43-749.

33. Este J.A CT. Current status and challenges of antiretroviral research and therapy. Antivir Res. 2010;85:25-33

34. Airoldi M ZM, Bisi L, Bini T, Antinori A, Mussini C, Bai F, Orofino G, Sighinolfi L, Gori A, Suter F, Maggiolo F. One-pill once-a-day HAART: a simplification strategy that improves adherence and quality of life of HIV-infected subjects Patient Prefer Adherence 2010;4:115-25.

35. Zinkernagel C TP, Rickenbach M, Amiet R, Ledergerber B, Volkart A.C, Rauchfleisch U, Kiss A, Werder V, Vernazza P, Battegay M. Swiss HIV Cohort Study: Importance of mental health assessment in HIV-infected outpatients. J Acquir Immune Defic Syndr. 2001;28:240-9.

36. Rueda S RJ, Mustard C, Bayoumi A, Lavis J.N, Rourke S.B,. Employment status is associated with both physical and mental health quality of life in people living with HIV. . Aids Care 2011;23:435-43

37. Call S.A KJC, Stewart K.E, Westfall A.O, Mallinger A.P, DeMasi R.A, Centor R, Saag M.S. Health-related quality of life and virologic outcomes in an HIV clinic. . Qual Life Res 2000;9:977-85 
Table 1: Respondents socio-demographic characteristics

\begin{tabular}{|c|c|c|}
\hline Variables & $\begin{array}{l}\text { Frequency } \\
\mathbf{N}=\mathbf{3 8 4}\end{array}$ & $\%$ \\
\hline \multicolumn{3}{|l|}{ Gender } \\
\hline Male & 162 & 42.0 \\
\hline Female & 222 & 58.0 \\
\hline \multicolumn{3}{|l|}{ Age Groups (years) } \\
\hline $19-30$ & 53 & 13.8 \\
\hline $31-40$ & 122 & 31.8 \\
\hline $41-50$ & 134 & 34.9 \\
\hline$=51$ & 75 & 19.5 \\
\hline \multicolumn{3}{|l|}{ Marital Status } \\
\hline Married & 298 & 77.6 \\
\hline Divorced & 9 & 2.3 \\
\hline Widowed & 44 & 11.5 \\
\hline Single & 33 & 8.6 \\
\hline \multicolumn{3}{|l|}{ Religion } \\
\hline Christianity & 172 & 44.8 \\
\hline Islam & 210 & 54.7 \\
\hline No religion & 2 & 0.5 \\
\hline \multicolumn{3}{|l|}{ Level of Education } \\
\hline No formal education & 57 & 14.8 \\
\hline Primary & 71 & 18.5 \\
\hline Secondary & 124 & 32.3 \\
\hline Tertiary & 132 & 34.4 \\
\hline \multicolumn{3}{|l|}{ Employment status } \\
\hline Employed & 287 & 74.7 \\
\hline Unemployed & 97 & 25.3 \\
\hline \multicolumn{3}{|l|}{ Income(\#) } \\
\hline$=20,000$ & 287 & 74.7 \\
\hline$>20,000$ & 97 & 25.3 \\
\hline
\end{tabular}

Table 2: Reported level of stigma experienced by Respondents $(\mathrm{N}=384)$

\begin{tabular}{lll}
\hline Domains & Weak (\%) & Strong (\%) \\
\hline Serotype & $101(26.3)$ & $283(73.7)$ \\
Disclosure concern & $126(32.8)$ & $258(67.2)$ \\
Social relationship & $298(77.6)$ & $86(22.4)$ \\
Acceptance & $155(40.4)$ & $229(59.6)$ \\
\hline
\end{tabular}


Table 3: Respondents' score for each of the Six Domains of QoL(N=384)

\begin{tabular}{lll}
\hline Domains & Poor (\%) & Good (\%) \\
\hline Physical & $65(16.9)$ & $319(83.1)$ \\
Psychological & $98(25.5)$ & $286(74.5)$ \\
Level of independence & $47(12.2)$ & $337(87.8)$ \\
Social Relation & $73(19.0)$ & $311(81.0)$ \\
Environmental & $37(9.6)$ & $347(90.4)$ \\
Spiritual/Religion/Belief & $232(60.4)$ & $152(39.6)$ \\
Overall Qol & $171(44.5)$ & $213(55.5)$ \\
\hline
\end{tabular}

Table 4: Regression Analysis of predictors of good QoL of respondents

\begin{tabular}{|c|c|c|c|c|c|}
\hline \multirow[t]{2}{*}{ Variables } & \multirow[t]{2}{*}{ p-value } & \multirow[t]{2}{*}{$\mathbf{S E}$} & \multirow{2}{*}{$\begin{array}{l}\text { Odd } \\
\text { Ratio } \\
\end{array}$} & \multicolumn{2}{|c|}{ C.I } \\
\hline & & & & Lower & Upper \\
\hline \multicolumn{6}{|l|}{ Demography } \\
\hline \multicolumn{6}{|l|}{ Age } \\
\hline$>30$ & 0.437 & 0.505 & 1.481 & 0.550 & 3.985 \\
\hline$=30$ & 0.662 & 0.524 & 1.257 & 0.450 & 3.512 \\
\hline \multicolumn{6}{|l|}{ Gender } \\
\hline Male & 0.442 & 0.282 & 0.805 & 0.464 & 1.399 \\
\hline Female & 0.442 & 0.282 & 0.805 & 0.464 & 1.399 \\
\hline \multicolumn{6}{|l|}{ Employment status } \\
\hline Employed & 0.585 & 0.445 & 0.784 & 0.328 & 1.875 \\
\hline Unemployed & 0.274 & 0.460 & 0.605 & 0.2467 & 1.489 \\
\hline \multicolumn{6}{|l|}{ Income / Month (N) } \\
\hline$=20,000$ & 0.536 & 0.300 & 1.204 & 0.669 & 2.166 \\
\hline$>20,000$ & 0.126 & 0.302 & 1.588 & 0.878 & 2.872 \\
\hline \multicolumn{6}{|l|}{ Education } \\
\hline Below tertiary & 0.730 & 0.429 & 1.159 & 0.500 & 2.690 \\
\hline Tertiary & 0.790 & 0.319 & 0.919 & 0.491 & 1.718 \\
\hline \multicolumn{6}{|l|}{ Marital Status } \\
\hline Married & 0.901 & 0.717 & 0.914 & 0.224 & 3.728 \\
\hline Divorced/separated & 0.962 & 0.354 & 0.983 & 0.492 & 1.966 \\
\hline \multicolumn{6}{|c|}{ Duration on HAART } \\
\hline$<3$ years & 0.012 & 0.129 & 0.720 & 0.052 & 0.075 \\
\hline $3-6$ years & 0.375 & 0.212 & 1.597 & 0.766 & 3.327 \\
\hline$=7$ & 0.145 & 0.321 & 1.596 & 0.851 & 2.994 \\
\hline \multicolumn{6}{|c|}{ CD4 Count (cells $\left./ \mathrm{mm}^{3}\right)$} \\
\hline $200-500$ & 0.187 & 0.377 & 0.608 & 0.290 & 1.274 \\
\hline$>500$ & 0.598 & 0.299 & 1.171 & 0.652 & 2.104 \\
\hline \multicolumn{6}{|l|}{ Co-infection } \\
\hline With Tuberculosis & 0.837 & 0.656 & 1.144 & 0.317 & 4.137 \\
\hline With other diseases & 0.905 & 0.852 & 0.903 & 0.170 & 4.798 \\
\hline \multicolumn{6}{|l|}{ Cost of care $(\mathrm{N})$} \\
\hline$=1,000$ & 0.535 & 0.387 & 1.271 & 0.596 & 2.714 \\
\hline$>1,000$ & 0.543 & 0.359 & 1.244 & 0.615 & 2.515 \\
\hline
\end{tabular}

